\title{
Action of Three Ectopeptidases on Corticotropin-Releasing Factor: Metabolism and Functional Aspects
}

\author{
James C Ritchie*, I,2, Thomas P Davis ${ }^{3}$ and Charles B Nemeroff ${ }^{2}$ \\ 'Department of Pathology \& Laboratory Medicine; ' Department of Psychiatry \& Behavioral Sciences, Emory University School of Medicine, \\ Atlanta, GA 30322, USA; ${ }^{3}$ Department of Pharmacology, School of Medicine, University of Arizona, Tucson, AZ 85724, USA
}

\begin{abstract}
Using purified enzyme preparations, we investigated the actions of angiotensin-converting enzyme, aminopeptidase $\mathrm{N}$, and endopeptidase 24.II on corticotropin-releasing factor (CRF). The effects of inhibition of these enzymes on CRF action in rat anterior pituitary cultures were also determined. Finally, specific inhibitors were used to evaluate ectopeptidase action on the regional brain metabolism of CRF. $K_{m}$ values for CRF were 165, 90, and $42 \mu \mathrm{M}$ for angiotensin-converting enzyme, aminopeptidase $\mathrm{N}$, and endopeptidase 24.II, respectively. A CRF metabolite profile for each enzyme was determined. In pituitary cultures, inhibition of endopeptidase 24.II and aminopeptidase $\mathrm{N}$ potentiated CRF-stimulated release of adrenocorticotropic hormone (ACTH). In rat pituitary and hypothalamus membrane preparations, specific inhibitor experiments indicated that CRF hydrolysis involved members of the neutral endopeptidase and aminopeptidase enzyme families. In cortex membranes, similar peptidase inhibition was without effect. These data support the hypothesis that ectopeptidases play a major role in CRF metabolism and biological function. Neuropsychopharmacology (2003) 28, 22-33. doi: I0.1038/sj.npp. I 3000 I4
\end{abstract}

Keywords: corticotropin-releasing factor; ectopeptidases; angiotensin-converting enzyme; neprilysin; aminopeptidase N; extracellular processing

\section{INTRODUCTION}

Corticotropin-releasing factor (CRF) is the primary central nervous system (CNS) neuroregulator of the pituitaryadrenal axis. Produced and secreted in the hypothalamus, this amidated 41 amino acid peptide (Vale et al, 1981) is transported within the hypothalamic-hypophysial portal system and acts on specific membrane receptors $\left(\mathrm{CRF}_{1}\right)$ on anterior pituitary corticotropes. Thus, CRF functions as a releasing factor causing the immediate release of stored and the synthesis of new adrenocorticotropic hormone (ACTH), $\beta$-endorphin, and other pro-opiomelanocortin (POMC)derived peptides. In addition to having a neuroendocrine role, CRF is synthesized in neurons at several extrahypothalamic sites within the CNS and the periphery. In the CNS, CRF functions as a neurotransmitter or neuromodulator (Morley and Levine, 1982; Fisher and Brown, 1984; Chappell et al, 1986; Valentino et al, 1986). In the periphery, the function of CRF remains obscure. Changes in plasma CRF concentrations have been observed during acute hemorrhage (Bruhn et al, 1987), insulin-induced hypogly-

*Correspondence: Dr JC Ritchie, Department of Pathology \& Laboratory Medicine, Room FI47A, Emory University Hospital, I 364 Clifton Road, Atlanta, GA 30322, USA, Tel: + I 404 712 7| 78, Fax: + I 404 7I2 4780, E-mail: jritchi@emory.edu

Received 16 January 2002; revised 20 May 2002; accepted 3 June 2002 Online publication: 5 June 2002 at http://www.acnp.org/citations/ Npp06050232I. cemia (Ellis et al, 1990), during pregnancy (Sasaki et al, 1984), and in depression (Catalan et al, 1998). CRF immunoreactivity has been observed in several peripheral tissues: adrenal medulla (Suda et al, 1984), testis (Yoon et $a l, 1988$ ), the endocrine pancreas (Petrusz et al, 1984), and in lymphocytes (Ritchie et al, 1986; Stephanou et al, 1990). CRF has also been shown to be locally secreted in the synovium of patients with rheumatoid arthritis and osteoarthritis (Crofford et al, 1993). Taken together, these findings support the hypothesis that CRF coordinates the mammalian organism's response to stress, including not just endocrine but immunologic, autonomic, and behavioral responses as well.

In the last two decades, ectopeptidases have been shown to be involved in the metabolism of a wide variety of small to moderate-length neuropeptides (neurotensin, substance $\mathrm{P}$, bradykinin, atrial-natriuretic factor, angiotensin, and the enkephalins). The three most investigated ectopeptidases in this regard have been angiotensin-converting enzyme (ACE, EC 3.4.15.1), aminopeptidase N (AP-N, EC 3.4.11.2), and neutral endopeptidase 24.11 (neprilysin, NEP, EC 3.4.24.11).

Structure-activity studies have demonstrated that rat/ human $(\mathrm{r} / \mathrm{h})$ CRF exhibits an $\alpha$-helical structure (residues 6-36), with the first half (6-20) being amphipathic (Romier et al, 1993; Dathe et al, 1996). In general, this type of secondary structure confers susceptibility to enzymatic cleavage; however, very little is known concerning the extracellular processing of $\mathrm{CRF}_{1-41}$. In an early study, Smith 
et al (1987) reported that CRF exists in at least five different molecular forms $\left(\mathrm{CRF}_{37-41}, \mathrm{CRF}_{36-41}, \mathrm{CRF}_{16-41}, \mathrm{CRF}_{1-41}\right.$, and an undetermined moiety) in the ovine tuberoinfundibular system and pituitary. Kertscher et al (1998) used highperformance liquid chromatography - mass spectrometry (LC/MS) and MS/MS techniques to characterize the degradation of CRF by whole rat brain preparations. These investigators identified $13 \mathrm{CRF}$ fragments in membrane preparations and concluded that the main enzymatic attack is on the central portion of the CRF molecule (positions 11-17).

In this study, we first characterized the actions of purified preparations of the ectoenzymes listed above on the r/h CRF molecule. Next, we determined the ability of specific ectopeptidase inhibitors to modulate CRF action in an anterior pituitary culture system. Finally, we evaluated the efficacy of specific enzyme inhibitors in protecting CRF from degradation by rat cortex, hypothalamus, and pituitary membrane preparations.

\section{MATERIALS}

\section{Animals}

Adult male Sprague-Dawley rats (150-350 g) were housed two per cage with free access to laboratory chow and water. The animals were housed in an environmentally controlled animal care facility, on a 12-h light/dark cycle (lights on at $0700 \mathrm{~h}$ ). Prior to the initiation of any experimental procedures, animals were handled extensively to minimize the effects of this stressor. All animal experiments were carried out in accordance with the Guide for the Care and Use of Laboratory Animals as adopted and promulgated by the National Institutes of Health.

\section{Enzyme Digestions}

All chemicals used in these experiments were reagent grade or analytical-spectral grade. The $\mathrm{NaCl}$ and $\mathrm{ZnCl}$ were from Fisher Scientific (Fair Lawn, NJ). Ultrapure Tris was obtained from Schwartz-Mann Biotech (Cleveland, OH), and glacial acetic acid was from EM Science (Gibbstown, $\mathrm{NJ})$. Angiotensin-converting enzyme (ACE), purified from rabbit lung, was purchased from Sigma Chemical (St Louis, MO). Three separate lots were used: 38F96101, 38F96103, and $38 \mathrm{~F} 9610$. The specific activity of the ACE preparations ranged from 2.4 to 3.3 units (modified Warburg-Christian) per milligram of protein. Porcine kidney aminopeptidase $\mathrm{N}$ was purchased from Calbiochem-Novabiochem Corp. (lot B09277; La Jolla, CA). This preparation had a specific activity of $12.9 \mathrm{u} / \mathrm{mg}$ protein. Purified neprilysin was a gift from G. Boileau (University of Montreal). This soluble recombinant enzyme preparation is catalytically identical to the wild-type enzyme (Fossiez et al, 1992). The enzyme lacks the hydrophobic membrane anchor of the wild-type enzyme and is $N$-glycosylated, but not to the same extent as the wild-type enzyme. This neprilysin preparation displayed a single band on sodium dodecylsulfate-polyacrylamide gel electrophoresis (SDS-PAGE), and had a protein concentration of $294 \mu \mathrm{g} / \mathrm{ml}$. Protein concentrations used in our calculations were those provided by the manufacturer or investigator and assume that all the protein present in the preparation is enzyme.

\section{HPLC}

All reagents used were purchased from JT Baker Inc., Phillipsburg, NJ. To select and optimize a system for CRF and its putative fragments, a variety of synthetic CRF analog peptides were used as markers. J Rivier (Salk Institute, La Jolla, CA) kindly supplied $\mathrm{r} / \mathrm{h} \mathrm{CRF}_{12-41}, \mathrm{CRF}_{37-41}, \mathrm{CRF}_{1-20}$, $\mathrm{CRF}_{6-33}, \mathrm{CRF}_{21-41}$, and $\mathrm{CRF}_{36-41}$. P Plotsky (Emory University, Atlanta, GA) donated $\mathrm{r} / \mathrm{h} \mathrm{CRF}_{1-8}$. Chiron Mimotopes (Emeryville, CA), synthesized $\mathrm{r} / \mathrm{h} \mathrm{CRF}_{4-7}, \mathrm{CRF}_{1-7}$, $\mathrm{CRF}_{1-11}, \mathrm{CRF}_{24-35}$, and $\mathrm{CRF}_{27-36}$. All peptides were free carboxylic acids.

\section{Pituitary Cultures}

Type IV collagenase was obtained from Worthington Biochemical, Freehold, NJ. Specific inhibitors of the peptidases (phosphoramidon, captopril, bestatin, and dlthiorphan) were purchased from Sigma Chemical. The serum-free medium $(\beta$-PJ) was prepared as described by Vale et al (1983b). Briefly, 11 of SFRE-199-2 medium (with Earle's salts) was prepared with $0.026 \mathrm{M}$ sodium bicarbonate, $0.015 \mathrm{M}$ HEPES, and $0.1 \%$ with bovine serum albumin. To this mixture we also added $10 \mathrm{ml}$ of $100 \times$ MEM vitamins and $10 \mathrm{ml}$ of $100 \times$ antibiotics solution (both from Sigma), and $25 \mu \mathrm{l}$ of a $100 \times$ trace metal solution prepared as described by Vale et al (1983a,b).

\section{EXPERIMENTAL PROCEDURES}

\section{Enzyme Digestions}

Initially, we used the digestion protocol outlined by Stephenson and Kenny (1987). Briefly, $20 \mu \mathrm{l}$ of peptide solution (containing $5-20 \mu \mathrm{g}$ of $\mathrm{CRF}_{1-41}$ in $0.001 \mathrm{M}$ acetic acid) was incubated with $20 \mu \mathrm{l}$ of enzyme solution (7.5$200 \mu \mathrm{g}$ of enzyme protein) in a $10 \times 75 \mathrm{~mm}$ silanized glass tube with $140 \mu \mathrm{l}$ of $0.05 \mathrm{M}$ Tris buffer. A pH of 7.0 was used for neprilysin digestions, $\mathrm{pH} 7.5$ for AP-N, and $\mathrm{pH} 7.6$ for ACE. The buffer for the ACE digestions also contained $0.3 \mathrm{M}$ $\mathrm{NaCl}$ and $10 \mu \mathrm{M} \mathrm{ZnCl}$. When used, inhibitors were incubated with the enzyme for $20 \mathrm{~min}$ before the addition of substrate. Tubes were set up on ice. To initiate digestions, tubes were covered with Parafilm, mixed, and placed in a shaking ( 100 oscillations $/ \mathrm{min}$ ) $37^{\circ} \mathrm{C}$ water bath. Incubation times varied with the nature of the experiment. Experiments included appropriate controls (substrate control, enzyme control, and inhibitor control). Incubations were terminated by adding $25 \mu \mathrm{l}$ glacial acetic acid and then placing the tubes in a boiling water bath for $5 \mathrm{~min}$. The reaction mixtures were then transferred to microcentrifuge vials and frozen at $-80^{\circ} \mathrm{C}$ until assay by HPLC.

In later experiments, we used the sequential method outlined by Rossomando (1989). In this method, one large incubation pool is assembled and samples are periodically removed from the reaction pool. Conditions for these assays were all optimized to ensure first-order kinetics. Termination of the reaction is accomplished by heating to $155^{\circ} \mathrm{C}$ in a sand bath for $10 \mathrm{~min}$. This method was used in all experiments to determine CRF enzyme kinetics and to isolate or sequence CRF digestion fragments. 


\section{HPLC}

Analyses were performed on a Beckman Instruments (San Ramon, CA) gradient HPLC system. The system consisted of two Model 110B pumps, a Model 166 programmable UV detector, a gradient maker, a Model 406 analog interface equipped with the pump control option, an 8780XR autosampler, and an IBM computer running Beckman System Gold software (version 6.02). The HPLC method outlined by Davis et al (1982), with minor modifications, was used to separate the enzyme digests. Chromatography was developed on a $5 \mu \mathrm{m}, 300 \AA, 0.46 \times 25 \mathrm{~cm}$ Vydac $\mathrm{C} 18$ column (Hysperia, CA). For method CRF-1, the flow rate was $1.5 \mathrm{ml} / \mathrm{min}$ and the column effluent was monitored at $210 \mathrm{nM}$. The mobile phase was composed of $0.05 \mathrm{M}$ $\mathrm{NaH}_{2} \mathrm{PO}_{4}$ (adjusted to $\mathrm{pH} 2.4$ with concentrated $\mathrm{H}_{3} \mathrm{PO}_{4}$ ) on the A pump and acetonitrile on the $\mathrm{B}$ pump. The computer initiated a linear gradient from 6 to $45 \%$ acetonitrile over $55 \mathrm{~min}, 2 \mathrm{~min}$ after sample injection. Sample size varied from 10 to $100 \mu \mathrm{l}$. For sequencing analyses, the effluent from the column was connected to a fraction collector and $0.5-\mathrm{min}(750 \mu \mathrm{l})$ fractions were collected. Using this method, as little as $1 \mu \mathrm{g}$ of $\mathrm{CRF}_{1-41}$ could be reliably detected $(2 \times$ signal to noise) .

To resolve the larger of the CRF fragments produced by the ectopeptidase digestions, a second gradient method (CRF-2) was also developed. This method was similar to CRF-1 except that the gradient ran from 20 to $45 \%$ acetonitrile in the same time frame.

For analysis, the chromatogram of the enzyme control preparation (containing all reaction components except $\mathrm{CRF}_{1-41}$ ) was electronically subtracted from the experimental digest's chromatogram to yield a composite chromatogram containing only the residual parent CRF peak and peaks formed in the digestion process.

\section{Peptide Sequencing}

Collected HPLC fractions were frozen at $-80^{\circ} \mathrm{C}$ and concentrated to dryness on a Savant Speed Vac Concentrator (Farmingdale, NY). The samples were then dissolved in $400 \mu \mathrm{l}$ of $0.5 \%$ trifluoroacetic acid (TFA) (Fisher Scientific, Fair Lawn, NJ) and loaded onto an Applied Biosystems Prospin (Foster City, CA) sample preparation cartridge. The cartridge was centrifuged at $5600 \times g$ and $10^{\circ} \mathrm{C}$ until the membrane was dry, usually about $6 \mathrm{~h}$. The membrane was removed from the cartridge and transported to the Howard Hughes Medical Institute Sequencing Facility (Duke University). Sequencing was performed by automated Edman degradation chemistry using an Applied Biosystems Model 470A sequencer with online HPLC amino acid analysis (o-PTH derivatization method). All CRF fragments reported on were sequenced at least twice from separate digestions.

\section{Pituitary Cultures}

To determine the importance of ACE, NEP, and AP-N in modulating the biological actions of CRF, we used a rat anterior pituitary culture model (with specific inhibitors of these enzymes) and measured the CRF-stimulated release of ACTH into the culture media. We used the culture method of Vale et al (1983b), with two modifications. In the initial tissue dissociation, we used type IV collagenase (Worthington Biochemical, Freehold, NJ) to preserve cell surface proteins. Dispersed cells were plated at $1 \times 10^{5}$ cells per well in the center 24 wells of a 48 -well tissue culture plate (Corning, Inc., Corning, NY); outer wells were filled with blank media to maintain hydration of the plate.

For experimental procedures, growth medium was gently removed from each well. The cells were washed three times $(1 \mathrm{ml} /$ well) with $\beta$-PJ medium that had been prewarmed to $37^{\circ} \mathrm{C}$. The plates, with fresh $\beta$-PJ medium, were then returned to the incubator for $1 \mathrm{~h}$. Enzyme inhibitors, when used, were applied during preincubation. The cells were then washed again $(1 \mathrm{ml} /$ well $)$ with fresh $\beta$-PJ medium. The wash was removed and fresh $\beta$-PJ medium was added. At this time, the inhibitors to be tested, control vehicles, and CRF ( $0.1 \mathrm{nM}$ final concentration) were applied to their respective wells. In each experiment, treatments were tested in triplicate. The cultures were incubated $\left(37^{\circ} \mathrm{C}\right)$ for various times, depending on the experimental procedure.

\section{ACTH Measurement}

We used the two-site immunoradiometric assay (IRMA) developed by the Nichols Institute (San Juan Capistrano, CA). Assays were run in duplicate and counted on a Packard Instruments (Downers Grove, IL) Multi-PRIAS-2 $\gamma$ counter. The sensitivity of the assay was $1 \mathrm{pg} / \mathrm{ml}(0.22 \mathrm{pmol} /$ 1) $\mathrm{ACTH}_{1-39}$. The method was chosen out of concern that the ectopeptidases present in pituitary cultures might degrade ACTH as well as CRF and so result in multiple ACTH fragments, each being measured as an ACTH molecule in a traditional radioimmunoassay. Additionally, Orth and Nicholson (1977) showed that chronically stimulated corticotropes release multiple forms of POMC fragments which might also crossreact in a traditional radioimmunoassay.

The IRMA assay is extremely specific, requiring binding at two sites ( $\mathrm{N}$ - and C-terminal directed) on the ACTH molecule to register a signal. The assay exhibits no crossreactivity with $\mathrm{ACTH}_{1-24}, \mathrm{ACTH}_{11-24}, \mathrm{ACTH}_{1-10}, \alpha-$ $\mathrm{MSH}, \beta$-MSH, $\beta$-LPH, and $\beta$-endorphin up to $100000 \mathrm{pg} / \mathrm{ml}$. No crossreactivity $(<0.001 \%)$ was demonstrated at concentrations up to $200 \mu \mathrm{g} / \mathrm{ml}$ for $\mathrm{CRF}_{1-41}$ and up to $10 \mu \mathrm{g} / \mathrm{ml}$ for any of the CRF fragment peptides described above.

The assay system, as configured by the manufacturer, is optimized to measure human ACTH in unextracted plasma accurately. To validate the measurement of rat ACTH in tissue culture media, rat ACTH standards were prepared in the $\beta$-PJ tissue culture media and assayed. The rat ACTH curve was virtually identical (human curve slope $=1.558$, rat curve slope $=1.511$ ) to the human ACTH curve, suggesting that the assay, configured in this manner, can accurately measure rat ACTH. Additionally, serial dilution of a rat pituitary culture specimen exhibited parallelism with the standard curves.

Over the length of this study, the interassay coefficients of variation $(\mathrm{CV})$ for a $7.27 \mathrm{pmol} / \mathrm{l}$ and a $68.48 \mathrm{pmol} / \mathrm{l}$ sample (33 and $311 \mathrm{pg} / \mathrm{ml}$ ) were 6.7 and $16.0 \%$, respectively $(n=25)$. The intra-assay CVs were 2.8 and $6.1 \%$, respectively, for the same specimens assayed in duplicate in the same number of assays. 


\section{In Vitro Digestions and Tissue Extraction}

Hypothalamic and prefrontal cortex membranes were harvested from normal male Sprague-Dawley rats in our laboratory. For studies of the anterior pituitary, tissues were obtained from Harlan Bioproducts for Science Inc (Indianapolis, IN). Tissues harvested by Harlan Bioproducts were shipped to the laboratory on dry ice overnight and were stored at $-80^{\circ} \mathrm{C}$ until use. In both cases, harvesting procedures were conducted in the following manner. Rats were decapitated and the brain and pituitary were quickly removed. Brains were frozen, ventral side up on dry ice and stored at $-80^{\circ} \mathrm{C}$ until dissection. Pituitaries were separated into anterior and posterior portions and then frozen in liquid nitrogen. On the day of an experiment, the hypothalamus and prefrontal cortex were isolated by freehand dissection on ice by a modification of the method of Glowinski and Iversen (1966). Samples were homogenized by hand, on ice in $0.05 \mathrm{M}$ Tris buffer, $\mathrm{pH} 7.60$, using a Potter-Elvehjem homogenizer with Teflon plunger (Bellco Glass, Inc, Vineland, NJ).

The extracts were centrifuged at $10000 \times g$ at $4^{\circ} \mathrm{C}$ for $10 \mathrm{~min}$. The pellet, containing ruptured cell membranes, was washed twice with the above buffer plus $0.5 \mathrm{M} \mathrm{NaCl}$ and centrifuged again as above. This wash was incorporated to dissociate any bound soluble enzymes from the cell membrane fragments. After the washes, the membrane fragments were resuspended in $0.05 \mathrm{M}$ Tris $+0.3 \mathrm{M}$ $\mathrm{NaCl}+10 \mu \mathrm{M} \mathrm{ZnCl}$, $\mathrm{pH}$ 7.60. Volumes for resuspension were determined for each tissue based on initial CRF digestion experiments. In general, volumes chosen produced extracts in which approximately $50 \%$ of $19.5 \mu \mathrm{M}$ $\mathrm{CRF}_{1-41}$ was degraded (based on peak area) within $1 \mathrm{~h}$ at $37^{\circ} \mathrm{C}$. Roughly, hypothalamic extracts were 1:4 (weight to volume), anterior pituitary extracts were $1: 20$, and prefrontal cortex extracts were 1:5.

Digestions were performed using the method of Stephenson and Kenny (1987) and optimized to first-order kinetics. The reaction volume was $180 \mu \mathrm{l}(100 \mu \mathrm{l}$ tissue extract, $20 \mu \mathrm{l}$ substrate, $20 \mu \mathrm{l}$ inhibitor, $40 \mu \mathrm{l}$ buffer). Subtracted (minus tissue control) experimental chromatograms were analyzed for loss of the $\mathrm{CRF}_{1-41}$ peak area and the formation of new (CRF fragment) peaks. For inhibition experiments, $\mathrm{CRF}_{1-41}$ peak areas in preparations containing specific enzyme inhibitors were compared with those containing no inhibitor to calculate the protective effect of each inhibitor.

\section{Statistical Analyses}

Immunoradiometric assay data are expressed as fmol $\mathrm{ACTH} / \mathrm{ml}$ tissue culture media (equivalent to $\mathrm{fmol} / 1 \times 10^{5}$ pituitary cells). Data for all treatment groups are expressed as the mean $(x)$ plus or minus the standard error of the mean (SEM). Student's $t$-test, Student-Newman-Keuls test for multiple comparisons, or Dunnett's test for multiple comparisons to a single mean were used for post hoc comparisons. For all parametric statistical methods, a $p$ value of $<0.05$ was considered significant.

The determination of the kinetic parameters for the three enzymes analyzed was accomplished by an indirect method using a less expensive substrate (neurotensin for ACE and neprilysin, leu ${ }^{5}$-enkephalin for AP-N) and a limited number of moderate CRF concentrations. This was done because of the high cost of CRF peptide and the necessity of using saturating concentrations $(\mathrm{mM})$ of substrate to guarantee meaningful kinetic data. In each case, the disappearance of substrate, as determined by peak area in the HPLC gradient, was measured. Using a computer program kindly supplied by SP Brooks (1992), standard Michaelis-Menten kinetic parameters $\left(K_{\mathrm{m}}\right.$ and $\left.V_{\max }\right)$ were determined for each enzyme preparation and the less expensive substrate. The process was then repeated with a known concentration of specific inhibitor (captopril for ACE, phosphoramidon for neprilysin, bestatin for AP-N), allowing the determination of $K_{\mathrm{m}}^{\prime}$. In all three cases, the inhibition was competitive. The $K_{\mathrm{m}}$ and $K_{\mathrm{m}}^{\prime}$ for each enzyme were then used to derive the inhibition constant $\left(K_{\mathrm{i}}\right)$ for the enzyme preparation. The velocity $v$ of the reaction was then determined for a moderate CRF concentration using the same preparation of enzyme. Additionally, the velocity $v^{\prime}$ was determined for $\mathrm{CRF}$ in the presence of the same inhibitor. The $K_{\mathrm{m}}$ of the enzyme for CRF was calculated by solving the two rate equations simultaneously:

$$
\frac{v}{v^{\prime}}=\frac{V_{\max } S}{K_{\mathrm{m}}+S}\left(\frac{K_{\mathrm{m}}^{\prime}+S}{V_{\max } S}\right)
$$

If the definition of $K_{\mathrm{m}}{ }^{\prime}$ is substituted in the above equation, it becomes

$$
\frac{v}{v^{\prime}}=\frac{K_{\mathrm{m}}\left(1+\frac{1}{K_{\mathrm{i}}}\right)+S}{K_{\mathrm{m}}+S}
$$

Using the $K_{\mathrm{i}}$ determined for the less expensive substrate, solving this equation yields a $K_{\mathrm{m}}$ for CRF. Once the $K_{\mathrm{m}}$ was known, the $V_{\max }$ was calculated from the rate equation and the $k_{\text {cat }}$ was calculated from the equation $k_{\mathrm{cat}}=V_{\mathrm{max}} / e_{0}$, where $e_{0}$ is the enzyme concentration used (in $\mu \mathrm{M} / \mathrm{l}$ ).

\section{RESULTS}

Figure la shows a representative chromatogram of $\mathrm{CRF}_{1-41}$ and Figure 1b, shows a mix of seven standard CRF fragment peptides. As can be seen from Figure 1b, this method is capable of resolving all the CRF fragment peptides tested, except $\mathrm{CRF}_{27-36}$, which is lost into the solvent front.

\section{Purified Enzyme Studies}

From initial experiments using the ACE preparation (data not shown), the following conditions were selected for comprehensive studies: $0.05 \mathrm{M}$ Tris buffer $+0.3 \mathrm{M}$ $\mathrm{NaCl}+10 \mu \mathrm{M} \mathrm{ZnCl} 2, \mathrm{pH} 7.6 ; 35.9 \mathrm{nM}(171 \mu \mathrm{g}) \mathrm{CRF}$; and 1.54-2.5 nM (277-450 $\mu \mathrm{g})$ ACE. Three sequential digestion experiments were performed. In each case, a large-volume reaction mix (total volume $1620 \mu \mathrm{l}$ ) was incubated at $37^{\circ} \mathrm{C}$, $200-\mu \mathrm{l}$ aliquots were removed at hourly intervals and chromatographed, and the peptide peaks were sequenced. Control digestions, including the CRF peptide and a heat- 


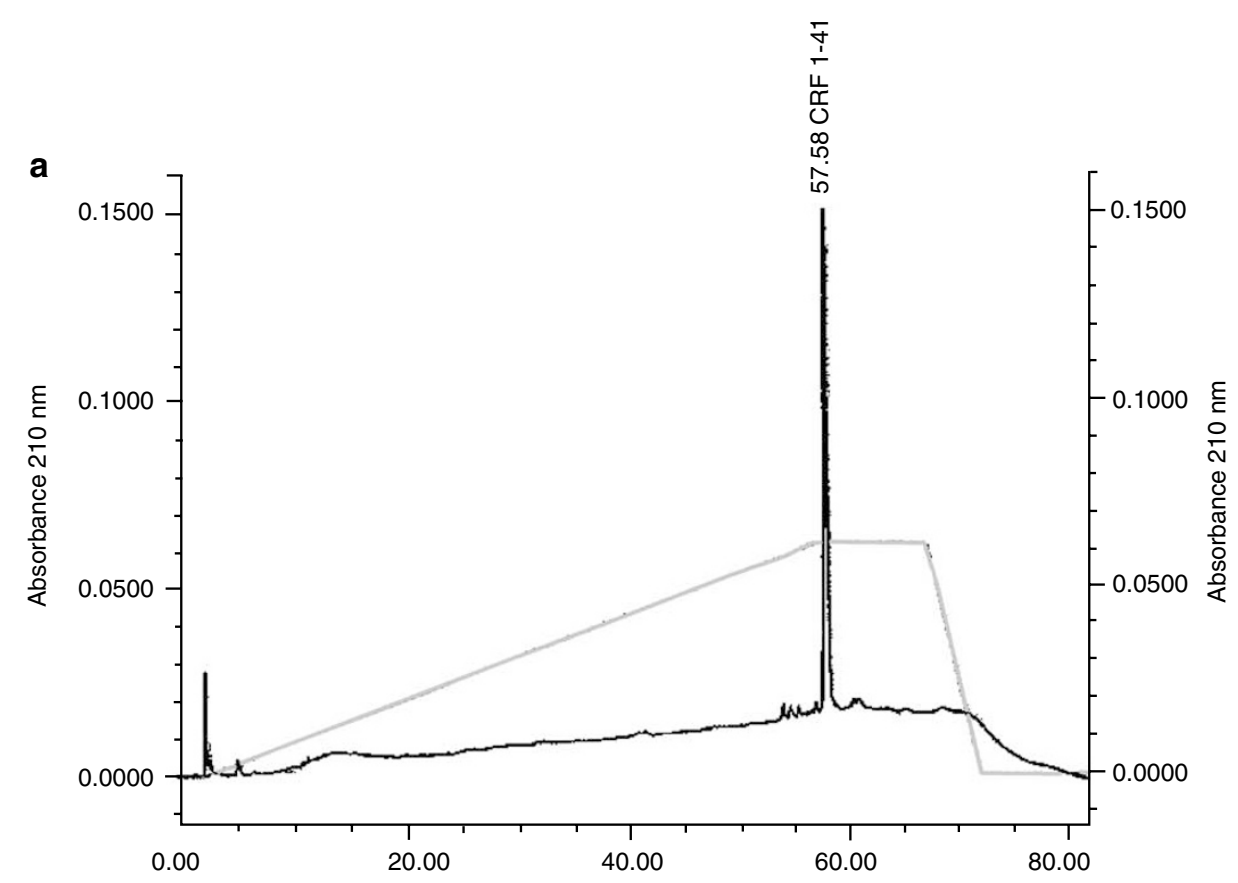

b

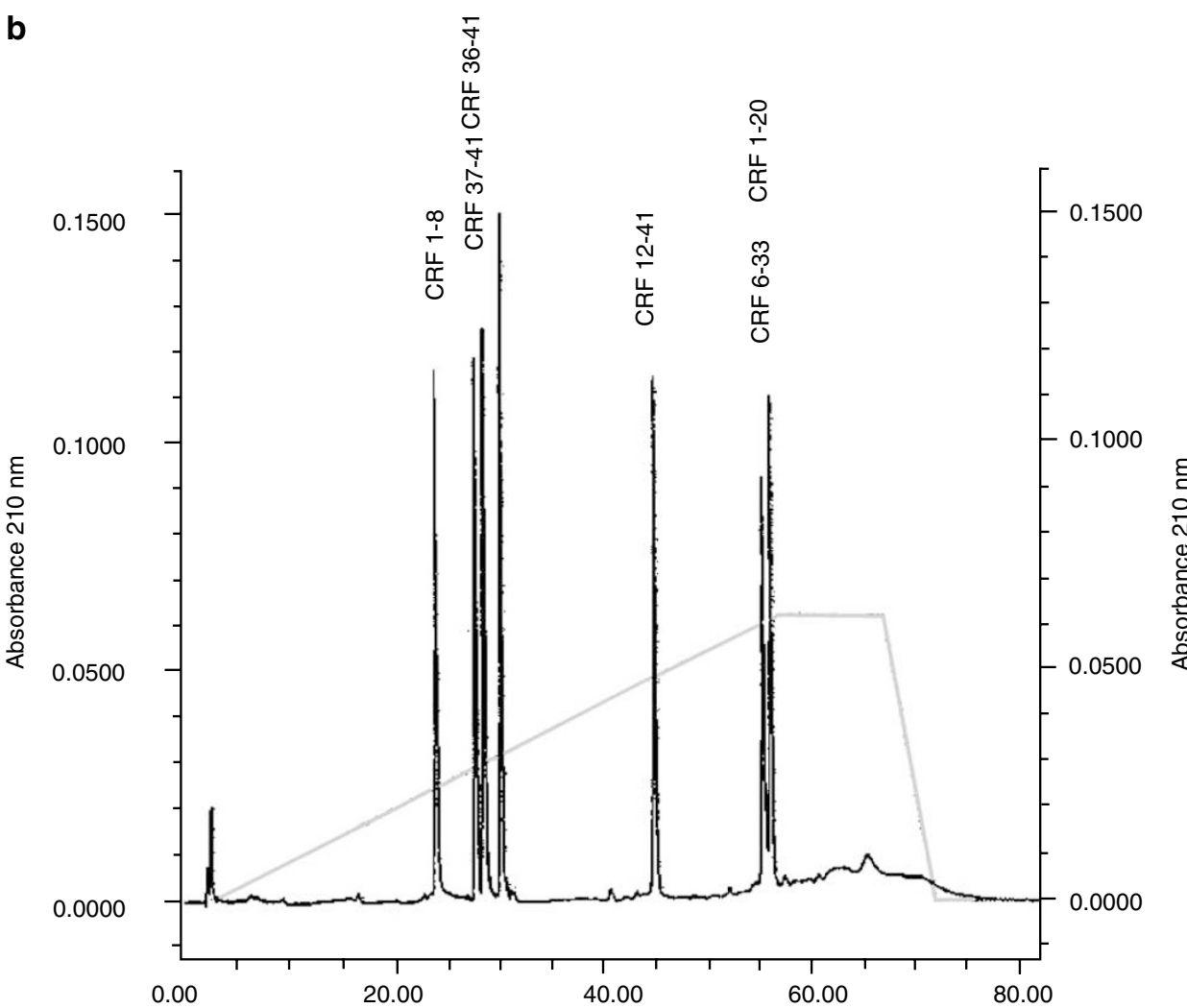

Figure I (a) $\mathrm{CRF}_{\mid-41}(\mathrm{I} 6 \mu \mathrm{g})$ in $100 \mu \mathrm{l} 0.05 \mathrm{M} \mathrm{NaH}_{2} \mathrm{PO}_{4}$ buffer, pH 2.4. HPLC method: CRF-I. (b) Seven CRF standard peptides, $7 \mu \mathrm{g}$ of each peptide.

inactivated enzyme preparation, were included in every experiment and were electronically subtracted from the experimental runs.

Figure 2 graphically depicts the generation of CRF fragment peptides during a typical ACE digestion experiment. As can be seen from Figure 2a, $\mathrm{CRF}_{1-27}$ and $\mathrm{CRF}_{1-36}$ are the primary daughter peptides formed, with $\mathrm{CRF}_{1-7}$ and $\mathrm{CRF}_{1-18}$ also being produced (Figure $2 \mathrm{~b}$ ).

Using the procedure described (in the Methods section) and the ACE-specific inhibitor captopril $\left(K_{\mathrm{i}}=1.7 \mathrm{nM}\right)$, the approximate $K_{\mathrm{m}}$ for CRF was calculated to be $165 \mu \mathrm{M}$, with $V_{\max }=0.6 \mu \mathrm{M} \mathrm{CRF}$ digested $/ \mathrm{min} / \mu \mathrm{M} \mathrm{ACE}$. 

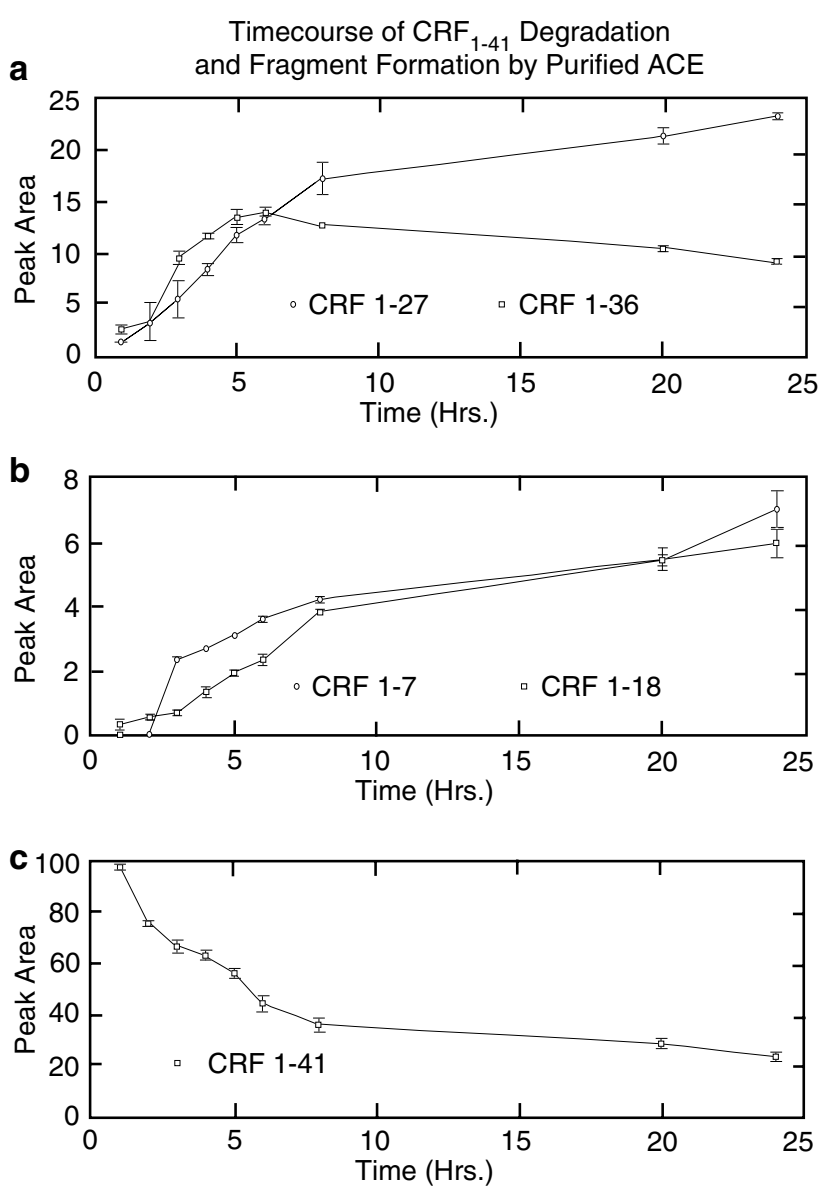

Figure $2 \mathrm{CRF}(\mathrm{I} \mid \mu \mathrm{g})+28 \mu \mathrm{g}$ purified $\mathrm{ACE}$ incubated at $37^{\circ} \mathrm{C}, \mathrm{pH} 7.6$ : (a) $\mathrm{CRF}_{1-27}$ and $\mathrm{CRF}_{1-36}$ formation, (b) $\mathrm{CRF}_{1-7}$ and $\mathrm{CRF}_{1-18}$ formation, (c) $\mathrm{CRF}_{|-4|}$ degradation. Values are means $\pm \operatorname{SEM}(n=3)$.

For neprilysin (NEP 24.11), we followed a similar approach. Optimal conditions (first order) were established, and sequential digestion experiments were performed using purified soluble recombinant enzyme. A large-volume reaction mixture $(1620 \mu \mathrm{l})$ containing $68 \mu \mathrm{g}(0.83 \mathrm{nmol})$ of enzyme, $171 \mu \mathrm{g}(35.9 \mathrm{nmol})$ of CRF, and $1210 \mu \mathrm{l} 0.05 \mathrm{M}$ Tris buffer, pH 7.0 was incubated at $37^{\circ} \mathrm{C} ; 200-\mu \mathrm{l}$ aliquots were removed at hourly intervals and chromatographed, and the peptide peaks were sequenced. Chromatograms from these experiments showed several CRF metabolite peaks with $R_{\mathrm{f}}=5.6,7.7,13.5,13.9,23.8,34.4,40.7,55.6,55.9$, and $56.5 \mathrm{~min}$. Sequence analyses determined that the peaks eluting at 5.6, 7.7, 13.5, 13.9, 55.6, 55.9, and $56.5 \mathrm{~min}$ were $\mathrm{CRF}_{18-20}, \mathrm{CRF}_{37-40}, \mathrm{CRF}_{1-7}, \mathrm{CRF}_{21-36}, \mathrm{CRF}_{1-39}, \mathrm{CRF}_{1-26}$, and $\mathrm{CRF}_{1-17}$, respectively. Unfortunately, the intermediately eluting peaks $(23.8,34.4$, and $40.7 \mathrm{~min})$ never attained sufficient size to allow for an accurate sequence determination. An additional peak eluting at $7.2 \mathrm{~min}$ was found to contain a mix of single amino acids.

Figure 3 illustrates the generation of CRF daughter peptides over time by purified neprilysin. As can be seen in Figure $3 \mathrm{a}, \mathrm{CRF}_{1-7}$ and $\mathrm{CRF}_{1-17}$ are formed at approximately equal rates for the first $10 \mathrm{~h}$ of digestion. Figure $3 \mathrm{c}$ shows the disappearance of the CRF parent peak and the generation of the most abundant metabolite peak, $\mathrm{CRF}_{1-26}$.
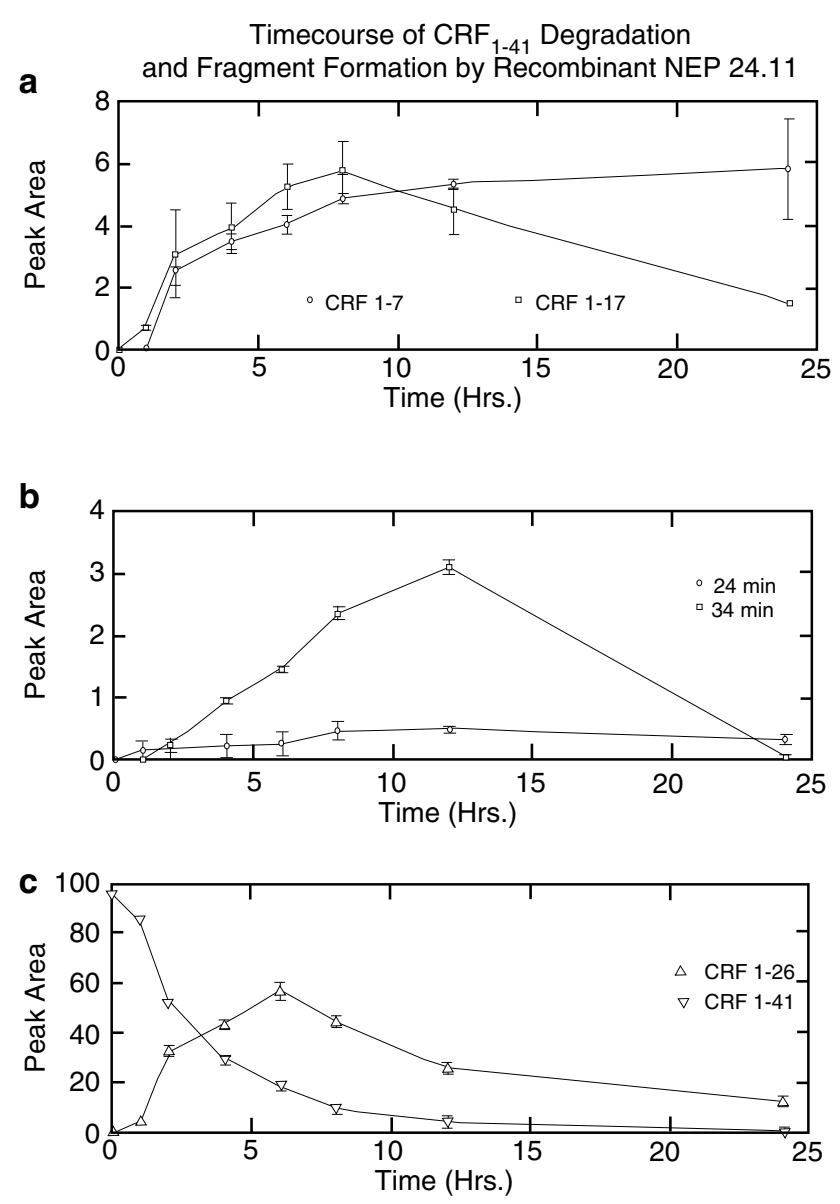

Figure $3 \mathrm{CRF}(13 \mu \mathrm{g})+1.47 \mu \mathrm{g}$ recombinant NEP 24.1 I incubated at $37^{\circ} \mathrm{C}$, pH 7.0: (a) $\mathrm{CRF}_{1-7}$ and $\mathrm{CRF}_{1-17}$ peak formation, (b) 24- and 34-min peak formation, (c) $\mathrm{CRF}_{|-4|}$ degradation and $\mathrm{CRF}_{1-26}$ peak formation. Values are means $\pm \operatorname{SEM}(n=3)$.

Using the procedure described (in the Methods section) and the neprilysin-specific inhibitor phosphoramidon $\left(K_{\mathrm{i}}=3 \mathrm{nM}\right)$, the approximate $K_{\mathrm{m}}$ for CRF was determined to be $42 \mu \mathrm{M}$, with $V_{\max }=1.26 \mu \mathrm{M}$ CRF digested $/ \mathrm{min} / \mu \mathrm{M}$ neprilysin.

Based on initial experiments, we chose the following conditions for our AP-N investigations: $847 \mu \mathrm{g}(3.02 \mathrm{nmol})$ of AP-N enzyme preparation, $300 \mu \mathrm{g}(63 \mathrm{nmol})$ of CRF, and $0.05 \mathrm{M}$ Tris buffer, $\mathrm{pH} 7.0$ (total volume $=1800 \mu \mathrm{l}$ ). Sequential digestion experiments were performed at $37^{\circ} \mathrm{C}$, as outlined for the previous two enzymes.

Sequence analysis of the complete set of fragment peptides produced was not possible as the many small peaks generated would have required the pooling of many digestions. We sequenced only fragment peaks that attained a relatively large area and also persisted over the length of the incubation. Five major fragment peaks were identified in these experiments. Additionally, many minor peaks, especially between 54 and $57 \mathrm{~min}$, were visible.

Sequence analysis revealed that a peak eluting at $4 \mathrm{~min}$ was a mixture of single amino acids. The remaining four peaks were identified as $\mathrm{CRF}_{17-34}, \mathrm{CRF}_{13-24}, \mathrm{CRF}_{2-24}$, and $\mathrm{CRF}_{2-15}$. Identification of C-terminal truncated fragments indicated that this AP-N preparation contained protease activity other than just AP-N. Literature review confirmed 
Timecourse of $\mathrm{CRF}_{1-41}$ Degradation

a
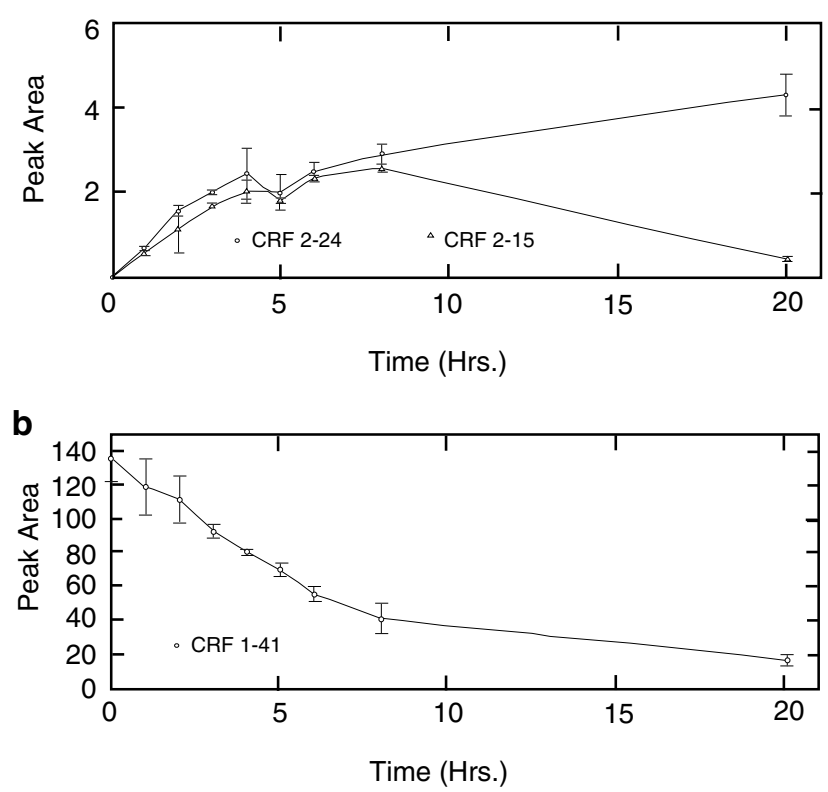

Figure $4 \mathrm{CRF}(\mathrm{I} / \mu \mathrm{g})+33 \mu \mathrm{g}$ purified $\mathrm{AP}-\mathrm{N}$ incubated at $37^{\circ} \mathrm{C}$, $\mathrm{pH}$ 7.5. (a) $\mathrm{CRF}_{2-24}$ and $\mathrm{CRF}_{2-15}$, (b) $\mathrm{CRF}_{1-4 \mid}$ degradation. Values are means $\pm \operatorname{SEM}(n=3)$
(Almenoff and Orlowski, 1983) that commercial preparations of AP-N are often contaminated with a weak metalloendopeptidase activity, which has a specificity similar to that of NEP. Figure 4 depicts the generation of $\mathrm{CRF}$ fragment peptides, over time, with the AP-N preparation. Figure 4a shows the generation of the $\mathrm{CRF}_{2-24}$ and $\mathrm{CRF}_{2-15}$ peaks. Although several other daughter peptides were recovered (eg $\mathrm{CRF}_{17-34}, \mathrm{CRF}_{13-24}$ ), these two were the only ones that demonstrated N-terminal truncation (ie AP$\mathrm{N}$ activity). No peptides were recovered that showed $\mathrm{N}$ terminal truncation and an intact C-terminus.

Using the procedure described (in the Methods section) and the aminopeptidase-specific inhibitor bestatin $\left(K_{\mathrm{i}}=78 \mathrm{nM}\right)$, the approximate $K_{\mathrm{m}}$ of this enzyme preparation (now known to contain at least two peptidases) for CRF was determined to be $90 \mu \mathrm{M}$, with $V_{\max }=1193 \mu \mathrm{M}$ CRF digested $/ \mathrm{min} / \mu \mathrm{M}$ AP-N preparation.

\section{CRF-Mediated ACTH Release}

To our knowledge, no studies on the time course of CRF action in the dissociated rat anterior pituitary culture model have been previously published. For purposes of this study, it was important to ascertain that the action of CRF was time limited in these cultures (ie once stimulated, the corticotropes did not remain activated indefinitely). To accomplish this, three time-course experiments were conducted. In each experiment, triplicate wells (each

Table I ACTH Secretion Rates from Cultured Rat Pituitary Cells

\begin{tabular}{lcrr}
\hline & \multicolumn{2}{c}{ Mean secretion rate \pm SEM (fmol ACTH/I $\times \mathbf{I 0}^{\mathbf{5}}$ cells $\left./ \mathbf{h}\right)$} \\
\cline { 2 - 4 } Time interval (h) & No treatment & \multicolumn{1}{c}{ Vehicle } & $\mathbf{0 . I} \mathbf{~ n M ~ C R F}$ \\
\hline $0.0-0.5$ & $3.6 \pm 1.8$ & $9.1 \pm 2.2$ & $48.3 \pm 5.1$ \\
$0.5-1.0$ & $-2.0 \pm 0.2$ & $-5.4 \pm 0.2$ & $2.7 \pm 0.2$ \\
$1.0-2.0$ & $-4.3 \pm 3.9$ & $1.1 \pm 0.9$ & $-14.8 \pm 4.1$ \\
$2.0-3.0$ & $5.2 \pm 2.0$ & $-2.7 \pm 0.7$ & $7.8 \pm 1.4$ \\
$3.0-4.0$ & $-10.0 \pm 0.6$ & $2.2 \pm 0.4$ & $7.3 \pm 3.0$ \\
$4.0-6.0$ & $6.4 \pm 2.2$ & $2.9 \pm 0.7$ & $6.5 \pm 0.7$ \\
$6.0-24.0$ & $0.6 \pm 0.8$ & $0.7 \pm 2.4$ & $1.6 \pm 1.7$ \\
\hline
\end{tabular}

Data derived from three experiments, with each time point measured in triplicate in each experiment. Time intervals are after the application of $0.1 \mathrm{nM} r / \mathrm{h}$ CRF. CRF vehicle is $0.001 \mathrm{M} \mathrm{HCl}$ in culture medium.

Table 2 Rat Pituitary Culture ACTH Secretion Rates after Treatment with CRF, Selected Ectopeptidase Inhibitors at Two Doses, or Inhibitor plus CRF

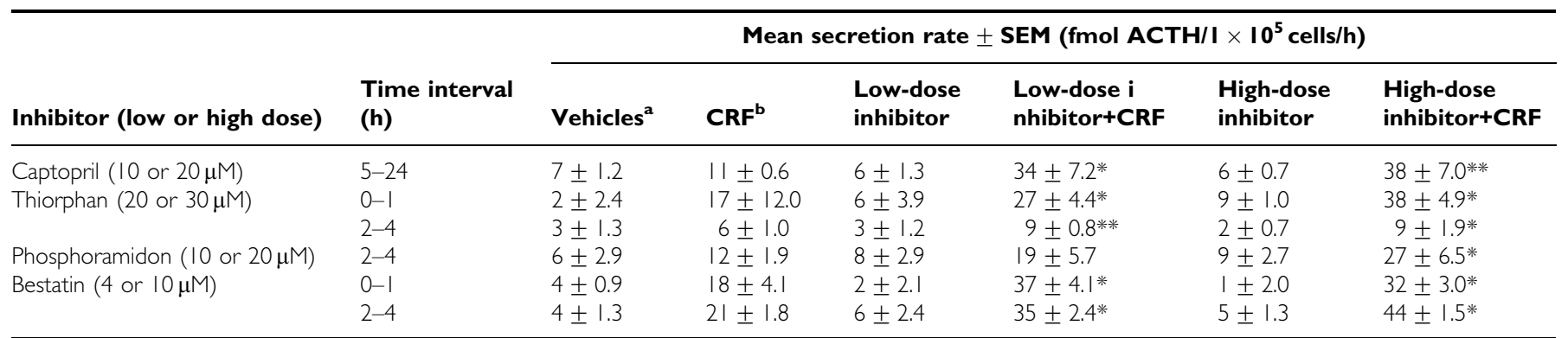

Results shown are means \pm SEM of at least three experiments, each done with triplicate wells. Results shown only for those time intervals for which a significant effect was observed. ${ }^{\mathrm{V} V}$ Vehicles were $0.00 \mathrm{I} \mathrm{M} \mathrm{HCl}$ in culture medium for CRF and $\beta$-PJ medium for the enzyme inhibitors. ${ }^{b} 0 . \mathrm{I}$ nM CRF throughout. *Significantly greater than CRF alone ( $p<0.05$, two-tailed $t$-test). *** Significantly greater than CRF alone $(p<0.005$, two-tailed $t$-test). 
Table 3 Effect of Three Endopeptidase Inhibitors on CRF Metabolism in Rat Membrane Preparations from Various Tissues

\begin{tabular}{lcllll}
\hline $\begin{array}{l}\text { Membrane } \\
\text { source }\end{array}$ & $\begin{array}{l}\text { Initial CRF } \\
\text { peak area }\end{array}$ & $\begin{array}{l}\text { Post-incubation } \\
\text { CRF peak area }\end{array}$ & $\begin{array}{l}\text { Phosphoramidon } \\
\mathbf{4 0} \boldsymbol{\mu M}\end{array}$ & $\begin{array}{l}\text { Bestatin } \\
\mathbf{4 0} \boldsymbol{\mu M}\end{array}$ & $\begin{array}{l}\text { Captopril } \\
\mathbf{4 0} \boldsymbol{\mu M}\end{array}$ \\
\hline Hypothalamus & $58 \pm 0.9$ & $27 \pm 0.4$ & $52 \pm 3.1^{* * *}$ & $40 \pm 1.8^{* * *}$ & $30 \pm 2.5$ \\
Pituitary & $103 \pm 6.3$ & $65 \pm 0.9$ & $83 \pm 3.6^{*}$ & $91 \pm 6.5^{*}$ & $64 \pm 3.5$ \\
Cortex & $24 \pm 1.1$ & $14 \pm 0.3$ & $14 \pm 0.3$ & $11 \pm 0.7^{*}$ & $12 \pm 0.6$ \\
\hline
\end{tabular}

Results are mean peak areas $\pm \operatorname{SEM}(n=3)$ for three experiments in which $20 \mu \mathrm{M}$ CRF was incubated for I $\mathrm{h}$ with the membrane preparation at $37^{\circ} \mathrm{C}$. *Significantly different from post-incubation CRF ( $p<0.05$, two-tailed $t$-test). ***ignificantly different from post-incubation CRF ( $p<0.005$, two tailed $t$-test).

containing $10^{5}$ cells) per time point were exposed to medium, medium $+\mathrm{CRF}$ vehicle $(=0.001 \mathrm{M} \mathrm{HCl})$, or medium $+0.1 \mathrm{nM} \mathrm{CRF}$ (final concentration in well). Culture media were harvested at several different time points and assayed for ACTH; the ACTH secretion rates were then calculated. Table 1 summarizes the results of these experiments. CRF triggers the immediate release of $\mathrm{ACTH}$, which is followed by a short quiescent period. The culture then returns to a phase of little or no release. These data are consistent with the termination of the action of CRF by some mechanism in the cultures and do not support the continued release of ACTH by the cells in response to a single stimulatory event.

To explore the role of the ectopeptidases on the nearphysiologic metabolism of CRF, the effects of inhibitors of these neuropeptidases on CRF-mediated ACTH release from rat pituitary cultures was investigated. Dose-response experiments (data not shown) were conducted with concentrations of inhibitor ranging from 0.5 to 10000 times the $K_{\mathrm{i}}$ for each inhibitor. These preliminary experiments indicated an effective concentration range of $10-20 \mu \mathrm{M}$ for captopril (ACE $\left.K_{\mathrm{i}}=1.7 \mathrm{nM}\right), 20-30 \mu \mathrm{M}$ for thiorphan (neprilysin $K_{\mathrm{i}}=4 \mathrm{nM}, \mathrm{ACE} K_{\mathrm{i}}=150 \mathrm{nM}$ ), $10-20 \mu \mathrm{M}$ for phosphoramidon (neprilysin $K_{\mathrm{i}}=3 \mathrm{nM}$ ), and $4-10 \mu \mathrm{M}$ for bestatin (AP-N $\left.K_{\mathrm{i}}=78 \mathrm{nM}\right)$.

On the basis of these investigations, a series of time nonreplacement experiments was conducted with each inhibitor. These experiments followed the release of ACTH over the time intervals $0-0.5,0.5-1.0,1.0-2.0,2.0-5.0$, and $5.0-24 \mathrm{~h}$ (with and without inhibitors) after stimulation by a single $\mathrm{r} / \mathrm{h}$ CRF dose $(0.1 \mathrm{nM})$. The results of these experiments are summarized in Table 2, which presents the mean secretion rates ( \pm SEM) from these experiments and displays only the time intervals for which a significant effect was observed.

The captopril + CRF treatment groups (10 and $20 \mu \mathrm{M})$ exhibited ACTH secretion rates significantly higher than those of the cells treated with CRF alone during the time interval from 5 to $24 \mathrm{~h}$ (Table 1). Additionally, treatment of the cultures with either captopril alone $(10$ or $20 \mu \mathrm{M})$ or vehicles was without effect. Captopril was without significant effect in prior time intervals (data not shown).

Two neprilysin inhibitors were evaluated for their ability to potentiate CRF-induced ACTH release from rat anterior pituitary cultures: phosphoramidon and thiorphan. (The latter is also known to inhibit ACE at high concentrations.) The results of these experiments are summarized in the second and third sections of Table 2. Thiorphan (20 and $30 \mu \mathrm{M})$ potentiated CRF-mediated ACTH secretion rates for the first $4 \mathrm{~h}$ after CRF treatment. Phosphoramidon $(20 \mu \mathrm{M})$ also increased the effects of CRF, but only in the 2 to 4 -h time interval. Both inhibitors were without effect when administered alone. These data indicate that neprilysin inhibition is effective in potentiating CRF-mediated ACTH secretion only during the initial phase of CRF stimulation, or that these inhibitors are inactivated by the cultures within this short time period.

Bestatin was used to inhibit aminopeptidase activity in the cultures. Inhibition by this compound ( 4 and $10 \mu \mathrm{M}$ ) significantly increased CRF-mediated rates of ACTH secretion over the 0 to 1 -h and 2 to 4 -h intervals. Again, when administered alone, bestatin and the vehicles were without effect on ACTH secretion.

\section{Tissue Studies}

In preliminary experiments, hypothalamic membrane preparations were exposed to a wide variety of peptidase inhibitors (chymostatin, captopril, EDTA, phosphoramidon, aprotinin, bestatin, leupeptin puromycin, E-64, ophenanthroline). Of the inhibitors tested, EDTA, $o$-phenanthroline, bestatin, and phosphoramidon were effective (to various degrees) in blocking CRF hydrolysis. Results for captopril were mixed. Thus, preliminary results indicated the involvement of a metallopeptidase in CRF degradation in this tissue.

Next, homogenized membranes were prepared from three different rat tissues: hypothalamus, anterior pituitary, and prefrontal cortex. These tissues were chosen to reflect sites where CRF is known to function in a differential manner (paracrine, neuroendocrine, and neurotransmitter functions, respectively).

Retention time $\left(R_{\mathrm{t}}\right)$ profiles of the major metabolite peaks were constructed for each tissue. The digestion of $\mathrm{CRF}_{1-41}$ by rat hypothalamic membranes produced metabolite peaks with the following mobilities: 47.2, 52.1, 52.9, 53.5, 55.0, and $59.9 \mathrm{~min}\left(\mathrm{CRF}_{1-41}\right.$ mobility $\left.=57.3 \mathrm{~min}\right)$. Among these peaks, the 52- and 53-min peaks were the largest in abundance. Pituitary membrane preparations, on the other hand, produced a different metabolite peak profile: 32.1, 36.0, $55.9,56.3,56.9,60.0$, and $61.5 \mathrm{~min}$. In this tissue, the 55.9and 56.3-min peaks achieved the largest peak area. Yet another metabolite profile was observed in cerebral cortical preparations: $27.1,32.4,35.6,46.8,55.2$, and $57.3 \mathrm{~min}$. In the cortical preparations, all the peaks were small and of approximately equal size.

Membrane preparations from the same three tissues were subsequently exposed to three protease inhibitors; these 


\section{Cleavage of $\mathrm{r} / \mathrm{h} \mathrm{CRF}_{1-41}$ by 3 Purified Endopeptidases \\ ( $\uparrow$ Indicates cleavage Sites)}

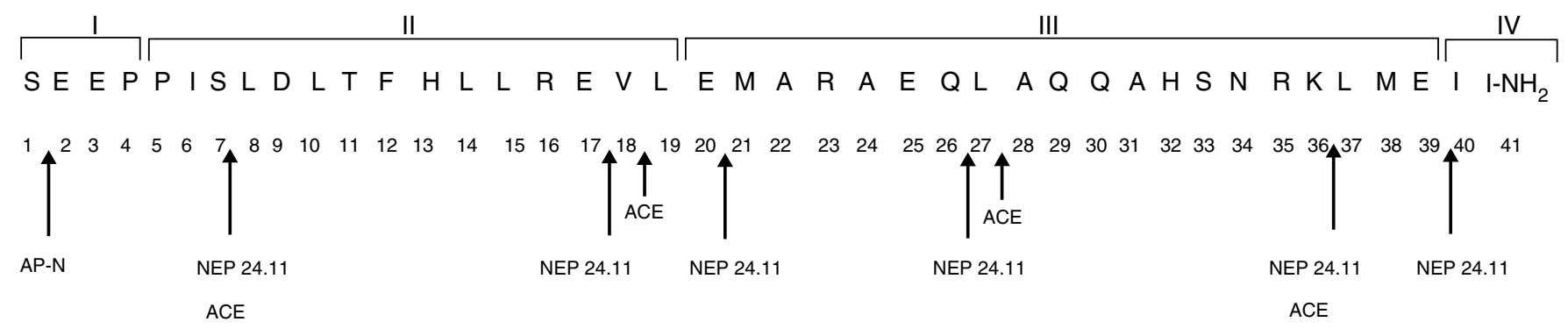

\begin{tabular}{|ccc|}
\hline \multicolumn{3}{c|}{ CRF Fragments Recovered } \\
\cline { 3 - 3 } NEP 24.11 & $\underline{\text { ACE }}$ & $\underline{\text { AP-N }}$ \\
$18-20$ & $1-7$ & $2-24^{*}$ \\
$37-40$ & $1-27^{*}$ & $2-15$ \\
$1-7$ & $1-36$ & \\
$1-39$ & $1-18$ & Several Unknowns \\
$1-26^{*}$ & & \\
$1-17$ & & * Largest Abundance \\
$21-36$ & & \\
\hline
\end{tabular}

Figure 5 Summary of $\mathrm{CRF}_{|-4|}$ hydrolysis by three ectopeptidases and cleavage products recovered. Fragments were recovered and sequenced at least twice from separate digestions.

data are summarized in Table 3. Both phosphoramidon and bestatin significantly blocked the metabolism of CRF in the hypothalamus and anterior pituitary. Blockade of neprilysin action (by phosphoramidon) was most protective in the hypothalamus, whereas inhibition of aminopeptidase (by bestatin) was slightly more protective in the pituitary. In both hypothalamus and pituitary tissues, inhibition of ACE (by captopril) did not have a significant effect on CRF metabolism. In the cortex, none of the three inhibitors tested was protective of CRF. The effect of bestatin on the cortex membranes was significant, but it appeared to potentiate the degradation of CRF rather than protect it.

\section{DISCUSSION}

The observed cleavage sites for ACE in CRF are shown in Figure 5. The predicted (Vale et al, 1983b) cleavage between Phe $^{12}$ and His ${ }^{13}$ either did not occur or the 1-12 fragment was rapidly degraded. From structure-activity studies (Rivier et al, 1984), it is clear that all the recovered fragment peptides would have reduced CRF activity. Two of the fragments (1-7 and 1-18) might also demonstrate antagonistic action at the CRF-R1 pituitary receptor.

The approximate $K_{\mathrm{m}}$ of ACE for $\mathrm{r} / \mathrm{h}$ CRF was determined to be $165 \mu \mathrm{M}$ and the $k_{\text {cat }}$ was $1.81 \mathrm{~min}^{-1}$. These constants appear high when compared with angiotensin $\mathrm{I}\left(K_{\mathrm{m}}=\right.$ $33 \mu \mathrm{M}$ and $\left.k_{\mathrm{cat}}=360 \mathrm{~min}^{-1}\right)$, neurotensin $\left(K_{\mathrm{m}}=14 \mu \mathrm{M}\right.$ and $\left.k_{\text {cat }}=3 \mathrm{~min}^{-1}\right)$, and substance $\mathrm{P} \quad\left(K_{\mathrm{m}}=25 \mu \mathrm{M}\right.$ and $k_{\text {cat }}=225 \mathrm{~min}^{-1}$ ); however, our $K_{\mathrm{m}}$ value compares well with the $K_{\mathrm{m}}$ for another hypothalamic releasing hormone, $\mathrm{GnRH} \quad\left(K_{\mathrm{m}}=167 \mu \mathrm{M}\right)$ (Skidgel and Erdos, 1985). The specificity indices $\left(k_{\mathrm{cat}} / K_{\mathrm{m}}\right)$ of ACE for CRF and $\mathrm{GnRH}$ are 0.011 and 1.3, respectively. Thus, in an equimolar mix of these two peptides with ACE, hydrolysis of $\mathrm{GnRH}$ would be favored by a factor of 100 .

Captopril, a specific competitive inhibitor of ACE, was tested for its ability to potentiate the action of CRF in rat pituitary cultures. Positive effects were observed at 10 and $20 \mu \mathrm{M}, 5-24 \mathrm{~h}$ after CRF treatment. As no precautions were taken to protect the inhibitor from degradation, the mechanism of this late effect is difficult to explain. Perhaps ACE inhibition causes only small, nonsignificant changes in ACTH release initially, but with these changes become additive over time, achieving significance only after $5 \mathrm{~h}$. Further study will be necessary to clarify this finding.

Further investigations were performed to assess the effects of ACE inhibition on CRF metabolism by membranes from three CNS regions (pituitary, hypothalamus, cerebral cortex). Cell membranes were disrupted by mechanical means to avoid concerns about enzymatic dissociation of the ectoenzymes. ACE inhibition had little or no effect on CRF metabolism in any of the membrane preparations.

Zacharieva et al (1991) previously studied the effects of ACE inhibition (by captopril) on the ACTH response to CRF in humans by conducting CRF challenge tests $(100 \mu \mathrm{g} r / \mathrm{h}$ CRF administered at $0900 \mathrm{~h}$ ) both before and after 3 days of captopril treatment $(100 \mathrm{mg} /$ day $)$ in 10 normal men. 
Captopril treatment decreased both basal and stimulated plasma ACTH levels. The authors attribute their findings to the effect of angiotensin II on ACTH release. These results also do not support a role for ACE in CRF metabolism, because higher ACTH concentrations would have been expected.

The sites of NEP cleavage in CRF are shown in Figure 5. Two cleavages are at the active center of the molecule (residues 5-19). Two of the cleavages are at the carboxyl terminal, maintenance of which is also known to be necessary for full biological activity (Vale et al, 1983a). The abundance and time course of the recovered peptide fragments (Figure 3) suggest an endopeptidase action beginning at the carboxyl terminal of the CRF molecule, with cleavages between $\mathrm{Glu}^{39}$ and $\mathrm{Ile}^{40}$ or $\mathrm{Lys}^{36}$ and $\mathrm{Leu}^{37}$. The decreasing abundance of the 1-39 fragment corresponds to an increasing abundance of the 1-26 fragment, and indicates that cleavage between $\mathrm{Gln}^{26}$ and $\mathrm{Leu}^{27}$ may occur next. For the sites shown in Figure 5, only 7 of the 20 possible cleavage products were recovered. The approximate $K_{\mathrm{m}}$ of NEP for CRF was calculated to be $42 \mu \mathrm{M}$. This is comparable to those of substance $\mathrm{P}\left(K_{\mathrm{m}}=32\right)$, CCK-8 $\left(K_{\mathrm{m}}=67\right)$, and neurotensin $\left(K_{\mathrm{m}}=78\right)$ (Kenny, 1993). The specificity index $\left(k_{\text {cat }} / K_{\mathrm{m}}\right)$ of NEP for CRF was determined to be 0.44 .

Thiorphan potentiated CRF-induced ACTH release from rat pituitary cultures at 20 and $30 \mu \mathrm{M}$, showing a significant effect within $1 \mathrm{~h}$. At the concentrations used, it is quite likely that thiorphan was inhibiting both neprilysin and ACE; however, the more specific neprilysin inhibitor phosphoramidon produced similar results at $20 \mu \mathrm{M}$.

Neprilysin is now known to be only one member of a family of neutral endopeptidases. Other members include the endothelin-converting enzymes (ECE-1 and ECE-2), KELL, PHEX, SEP/NEP-2, and XCE/DINE (Valdenaire et al, 1999; Ghaddar et al, 2000; Kiryu-Seo et al, 2000; Turner et al, 2001). SEP and XCE have been reported in brain and pituitary; both are sensitive to thiorphan and phosphoramidon, although at different levels. This might explain why thiorphan and phosphoramidon (molecules with similar $K_{\mathrm{i}}$ values for neprilysin) had different effects on CRF-mediated ACTH secretion in cultured pituitary cells.

In membrane extracts from the three CNS regions, NEP inhibition ( $40 \mu \mathrm{M}$ phosphoramidon) blocked $40 \%$ of $\mathrm{CRF}$ hydrolysis in the hypothalamus and $18 \%$ of CRF hydrolysis in the pituitary, but was without effect in cerebral cortex preparations.

After these experiments were completed, we discovered that the AP-N preparation used here contained an additional endopeptidase activity. Further studies with purified aminopeptidase $\mathrm{N}$ will be necessary to elucidate the exact nature of AP-N action on CRF; however, the recovery of $\mathrm{N}$-terminus truncated $\mathrm{CRF}$ fragments (Figure 5) indicates that AP-N can act on CRF (at least the terminal serine). Determination of the true $\mathrm{K}_{\mathrm{m}}$ and $V_{\max }$ of AP-N for CRF will require further study with a purified AP-N preparation.

An intact amino terminus appears to be important to protect the active center of the CRF molecule (i.e., $\mathrm{CRF}_{5-19}$ ) from proteolytic attack and to maintain its secondary structure. It is generally accepted that $\mathrm{N}$-terminal prolines block hydrolysis by aminopeptidases; however, removal of the first three residues by an aminopeptidase may render the molecule susceptible to subsequent attack by prolylendopeptidase. This may be especially important because it is this portion of the molecule that is exposed when CRF is attached to its binding protein (Potter et al, 1991).

The aminopeptidase inhibitor bestatin $(4$ and $10 \mu \mathrm{M})$ was effective in potentiating ACTH release from rat pituitary cultures at $1 \mathrm{~h}$, and the effect persisted for $4 \mathrm{~h}$. Due to the nonspecificity of bestatin, these data can be interpreted only as implicating the aminopeptidase family in terminating CRF action in the pituitary.

Bestatin blocked 20\% of the hydrolysis of CRF by rat hypothalamic membranes and $25 \%$ in rat pituitary membrane preparations. In rat cerebral cortex membranes, however, bestatin appeared to potentiate the degradation of CRF.

Two reports have documented the CNS actions of potential CRF fragment peptides. Nomizu and Miyamoto (1989) observed that fragments of CRF containing the ProPro-Ile-Ser sequence produced convulsions in mice when injected intracerebroventricularly (i.c.v.). The authors state that this sequence is not contained in any other biologically active peptide. They found that $\mathrm{CRF}_{4-6}$ exhibited the strongest effect. This fragment was not identified in any of the digestions we performed; however, the 1-7 fragment was produced by ACE and NEP.

A second report (Diamant and De Wied, 1993) describes the behavioral, autonomic, and endocrine effects of several CRF fragments. The 1-41, 28-41, and 34-41 fragments were found to attenuate passive avoidance behavior when injected i.c.v. in rats. The 34-41 fragment and the parent molecule produced tachycardia when injected i.c.v., whereas the 28-41 and 1-8 fragments were without effect. Both the parent molecule and the 34-41 fragment caused an increase in grooming behavior. The authors conclude that the dissociation of these effects suggests the possible existence of peptide fragments of $\mathrm{CRF}_{1-41}$ in the CNS, with distinct biological activity, acting on different receptors (CRF-R1 and CRF-R2) (Lovenberg et al, 1995).

None of the above-mentioned peptide fragments were isolated in our study. We did not find cleavage between $\mathrm{Ser}^{33}$ and $\mathrm{Asn}^{34}$ by the enzymes analyzed in this study.

The current work complements and extends the work of Kertscher et al (1998). Using LC/MS and MS/MS techniques, this group characterized CRF degrading activity in both membrane and cytosol preparations from whole rat brain. Although they, too, were unable to identify precisely the enzyme (or enzymes) responsible for CRF degradation, they did identify it 'as most likely a metallopeptidase with properties similar to those of endopeptidase 24.15 or 24.16 .' Specific inhibitors of both these enzymes (CFP-A-A-pAB and Pro-Ile, respectively), however, were unable to block the CRF degrading activity of their preparations. Additionally, they noted that cleavage of the first serine residue is strongly inhibited by bestatin but not by puromycin, ruling out the puromycin-inhibited aminopeptidase.

Our results with the purified ectopeptidases (Figure 5) support the Kertscher group findings. We found that the AP-N preparation we used did indeed cleave the terminal serine from the CRF molecule (other cleavage products recovered were most probably due to contamination of this preparation with an unknown metallopeptidase). In the bioactive region of the molecule (5-19), we found cleavages 
by purified ACE and recombinant neprilysin at positions 7$8,17-18$, and 18-19. In the carboxyl region of CRF, we also found cleavage sites at 20-21, 26-27, 27-28, 36-37, and 3940. Although our recovered fragments do not match those of Kertscher et al (1998) exactly (owing most likely to different specific peptidases involved in CRF catabolism by whole brain), our results do support the idea of three major areas of cleavage susceptibility within the CRF molecule. Additionally, using purified ectopeptidases we have identified four cleavage sites in the highly conserved, bioactive region of the molecule where a single cleavage would inactivate CRF.

We also determined the effect of ectopeptidase inhibition on CRF endocrine function, namely ACTH release and production, in rat pituitary cultures. Although our experiments lacked a positive control for CRF metabolism (ie coincubation of radiolabeled $\mathrm{CRF}$ ) and were complicated by the known endocytosis of the CRF-receptor complex in this culture system, (Childs, 1986) they did show the increased release of ACTH when specific ectopeptidases are inhibited. Note that these were acute static cultures, where only one in 20 cells is thought to be a corticotrope (Vale et al, 1983a). Thus, the fact that some of the inhibitors were active only over prolonged periods and at high concentrations may be an artifact of the culture system. Differences in the half-life of CRF between the digestion and in vitro experiments may be explained by the CRF concentrations used $(22 \mathrm{mM}$ vs $0.1 \mathrm{nM}$ ), and the amounts of available enzyme, in the two types of experiments.

In conclusion, $\mathrm{r} / \mathrm{h} \mathrm{CRF}_{1-41}$ was shown to be susceptible to digestion by ACE, neprilysin, and AP-N. Inhibition of these peptidases produces a rapid and prolonged (1-24h) potentiation of CRF-stimulated ACTH release in rat anterior pituitary cultures. CRF digestion by rat pituitary, hypothalamus, and cerebral cortex membranes appears to be mediated by different endopeptidases in each tissue and may result in the formation of different (tissue-specific) CRF fragment peptides. Thus, the enzymes that catabolize CRF may have a role in regulating CRF function in the CNS and throughout the entire endocrine system. Further studies will be necessary to explore this exciting possibility.

\section{ACKNOWLEDGEMENTS}

This work was supported by NIMH Grants MH-59833 and MH-58922. We thank the staff of the Duke University Howard Hughes Peptide Sequencing Facility for their kind assistance and patience.

\section{REFERENCES}

Almenoff J, Orlowski M (1983). Membrane-bound kidney neutral endopeptidase: interaction with synthetic substrates, natural peptides, and inhibitors. Biochemistry 2: 590-599.

Brooks SPJ (1992). A simple computer program with statistical tests for the analysis of enzyme kinetics. Biotechniques 13: 906911.

Bruhn TO, Engeland WC, Anthony ELP, Gann DS, Jackson IMD (1987). Corticotropin-releasing factor in dog adrenal medulla is secreted in response to hemorrhage. Endocrinology 120: 25-33.
Catalan R, Gallart JM, Castellanos RM, Galard R (1998). Plasma corticotropin-releasing factor in depressive disorders. Biol Psychiatry 44: 15-20.

Chappell PB, Smith MA, Kilts CD, Bissette G, Ritchie J, Anderson C et al (1986). Alterations in CRF-like immunoreactivity in discrete brain regions after acute and chronic stress. J Neurosci 6: 2908-2914.

Childs GV, Morell JL, Niendorf A, Aguilera G (1986). Cytochemical studies of corticotropin-releasing factor (CRF) receptors in anterior lobe corticotropes: binding, glucocorticoid regulation, and endocytosis of [biotinyl-Ser ${ }^{1}$ ] CRF. Endocrinology 119: 2129-2142.

Crofford LJ, Sano H, Karalis K, Friedman TC, Epps HR, Remmers $\mathrm{EF}$ et al (1993). Corticotropin-releasing hormone in synovial fluid and tissues of patients with rheumatoid arthritis and osteoarthritis. J Immunology 151: 1587-1596.

Dathe M, Fabian H, Gast K, Zirwer D, Winter R, Beyermann M et al (1996). Conformational differences of ovine and human corticotropin releasing hormone: A CD, IR, NMR and dynamic light scattering study. Int J Pept Protein Res 47: 383-393.

Davis TP, Schoemaker H, Chen A, Yamamura HI (1982). High performance liquid chromatography of pharmacologically active amines and peptides in biological materials. Life Sci 30: 971-987.

Diamant M, De Wied D (1993). Structure-related effects of CRF and CRF-derived peptides: dissociation of behavioral, endocrine and autonomic activity. Neuroendocrinology 57: 1071-1081.

Ellis MJ, Schmidli RS, Donald RA, Livesey JH, Espiner EA (1990). Plasma corticotropin-releasing factor and vasopressin responses to hypoglycemia in normal man. Clin Endocrinol 32: 93-100.

Fisher LA, Brown MR (1984). Corticotropin-releasing factor and angiotensin II: comparison of CNS actions to influence neuroendocrine and cardiovascular function. Brain Res 296: 41-47.

Fossiez F, Lemay G, Labonte N, Parmentier-Lesage F, Boileau G, Crine $P$ (1992). Secretion of a functional soluble form of neutral endopeptidase-24.11 from a baculovirus-infected insect cell line. Biochem J 284: 53-59.

Ghaddar G, Ruchon AF, Carpentier M, Marcinkiewicz M, Seidah NG, Crine P et al (2000). Molecular cloning and biochemical characterization of a new mouse testis soluble-zinc-metallopeptidase of the neprilysin family. Biochem J 347: 419-429.

Glowinski J, Iversen LL (1966). Regional studies of catecholamines in the rat brain. J Neurochem 13: 665-669.

Kenny J (1993). Neuropeptide processing and metabolism: molecular and clinical aspects. Biochem Soc Trans 21: 663-668.

Kertscher U, Beyermann M, Krause E, Furkert J, Berger H, Bienert $\mathrm{M}$ et al (1998). The degradation of corticotropin-releasing factor by enzymes of the rat brain studied by liquid chromatographymass spectrometry. Peptides 19: 649-658.

Kiryu-Seo S, Sasaki M, Yokohama H, Nakagomi S, Hirayama T, Aoki S et al (2000). Damage-induced neuronal endopeptidase (DINE) is a unique metallopeptidase expressed in response to neuronal damage and activates superoxide scavengers. Proc Natl Acad Sci USA 97: 4345-4350.

Lovenberg TW, Liaw CW, Grigoriadis DE, Clevenger W, Chalmers DT, De Souza EB et al (1995). Cloning and characterization of a functionally distinct corticotropin-releasing factor receptor subtype from rat brain. Proc Natl Acad Sci USA 92: 836-840.

Morley JE, Levine AS (1982). Corticotropin-releasing factor, grooming and ingestive behavior. Life Sci 31: 1459-1464.

Nomizu M, Miyamoto M (1989). Convulsant peptides related to corticotropin-releasing factor (CRF). Brain Res 505: 326-328.

Orth DN, Nicholson WE (1977). Different molecular forms of ACTH. Ann NY Acad Sci 297: 27-46.

Petrusz P, Merchenthaler I, Ordronneau P Maderdrut JL, Vigh S, Schally AV (1984). Corticotropin-releasing factor (CRF)-like 
immunoreactivity in the gastro-entero-pancreatic endocrine system. Peptides 5: 71-78.

Potter E, Behan D, Fischer W, Linton EA, Lowry PJ, Vale WW (1991). Cloning and characterization of the cDNAs for human and rat corticotropin-releasing factor-binding proteins. Nature 349: 423-426.

Ritchie JC, Owens MJ, O'Connor LW, Kegelmeyer AE, Walker JT, Stanley $\mathrm{M}$ et al (1986). Measurement of ACTH and CRF immunoreactivity in adrenal gland and lymphocytes. Soc Neurosci Abstr 12: 1041.

Rivier J, Rivier C, Vale W (1984). Synthetic competitive antagonists of corticotropin-releasing factor: effect on ACTH secretion in the rat. Science 224: 889-891.

Romier C, Bernassau JM, Cambillau C, Darbon H (1993). Solution structure of human corticotropin-releasing factor by ${ }^{1} \mathrm{H}$ NMR and distance geometry with restrained molecular dynamics. Protein Eng 6: 149-156.

Rossomando EF (1989). Application of high-performance liquid chromatography to enzyme activity determination. J Chromatogr 492: 361-375.

Sasaki A, Liotta AS, Luckey MM, Margioris AN, Suda T Krieger DT (1984). Immunoreactive corticotropin-releasing factor is present in human maternal plasma during the third trimester of pregnancy. J Clin Endocrinol Metab 59: 812-814.

Skidgel RA, Erdos EG (1985). Novel activity of human angiotensin I converting enzyme: release of the $\mathrm{NH}_{2}$ - and $\mathrm{COOH}$ terminal tripeptides from luteinizing hormone-releasing hormone. Proc Natl Acad Sci USA 82: 1025-1029.

Smith AI, Engler D, Fullerton ML, Pham J, Wallace C, Morgan FJ et al (1987). Post-translational processing of corticotropin-releasing factor in the ovine tuberoinfundibular system and pituitary. Ann N Y Acad Sci 512: 24-47.

Stephanou A, Jessop DS, Knight RA, Lightman SL (1990). Corticotropin-releasing factor-like immunoreactivity and mRNA in human leukocytes. Brain Behav Immun 4: 67-73.

Stephenson SL, Kenny AJ (1987). The hydrolysis of $\alpha$-human atrial natriuretic peptide by pig kidney microvillar mem- branes is initiated by endopeptidase 24-11. Biochem J 243: 183-187.

Suda T, Tomori N, Tozawa F, Demura H, Shizume K, Mouri T et al (1984). Immunoreactive corticotropin and corticotropinreleasing factor in human hypothalamus, adrenal, lung cancer and pheochromocytoma. J Clin Endocrinol Metab 58: 919-924.

Turner AJ, Isaac RE, Coates D (2001). The neprilysin (NEP) family of zinc metalloendopeptidases: genomics and function. Bioessays 23: 261-269.

Valdenaire O, Grayson RJ, Faull RLM, Schweizer A (1999). XCE, a new member of the endothelin-converting enzyme and neutral endopeptidase family, is preferentially expressed in the CNS. Mol Brain Res 64: 211-221.

Vale W, Rivier C, Brown MR, Spiess J, Koob G, Swanson L et al (1983a). Chemical and biological characterization of corticotropin-releasing factor. Rect Prog Horm Res 39: 245-270.

Vale W, Vaughan J, Yamamoto G, Bruhn T, Douglas C, Dalton D et al (1983b). Assay of corticotropin-releasing factor. In: Conn PM (ed). Methods in Enzymology. Academic Press: New York, Vol 103: pp 565-577.

Vale W, Spiess J, Rivier C, Rivier J (1981). Characterization of a 41-residue ovine hypothalamic peptide that stimulates secretion of corticotropin and B-endorphin. Science 213: 1394-1397.

Valentino RL, Martin DL, Suzuki M (1986). Dissociation of locus coeruleus activity and blood pressure: effects of clonidine and corticotropin-releasing factor. Neuropharmacology 25: 603-610.

Yoon DJ, Sklar C, David R (1988). Presence of immunoreactive corticotropin-releasing factor in rat testis. Endocrinology 122: 759-761.

Zacharieva S, Matrozov P, Stoeva I, Andonova K (1991). The effect of angiotensin-converting enzyme inhibition on ACTH response to corticotropin-releasing hormone $(\mathrm{CRH})$ in normal men. Horm Metab Res 23: 245-246. 